UDK 37.014.12:27-74

$37.014 .12: 341$

https://doi.org/10.31337/oz.77.1.5

Pregledni rad

Primljeno: 23.7.2021

Prihvaćeno: 6.12.2021.

\title{
Pravo djeteta na odgoj i obrazovanje u kanonskom i međunarodnom pravu
}

\author{
Klara Ćavar*, Marija Džinić ${ }^{* *}$
}

\begin{abstract}
Sažetak
Pravo na odgoj i obrazovanje jedno je od temeljnih ljudskih prava. Njegov razvoj i status određen je kulturno-civilizacijskim dosegom konkretne povijesne epohe. Tek je humanizam u obrazovanju prepoznao temelj izgradnje slobodnoga društva. Članak obrađuje izabrane dokumente kanonskoga i međunarodnoga prava usmjerene odgoju i obrazovanju. Cilj je utvrditi mjeru utjecaja Crkve i svjetovnih vlasti na uvažavanje prava djeteta, kojemu, uz ostalo, pripada pravo na obrazovanje.

Ključne riječi: dijete; odgoj; obrazovanje; kanonsko pravo; međunarodno pravo
\end{abstract}

\section{Uvod}

Pravo na odgoj i obrazovanje jedno je od temeljnih ljudskih prava. To je pravo Drugi vatikanski sabor nazvao svetim, a zakonodavstvo Crkve štiti ga, promiče i regulira vlastitim odredbama. Prvi dio izlaganja analizira povijesni razvoj prava na odgoj i obrazovanje u kanonskom zakonodavstvu. Početak odredbi uzetih u razmatranje seže od enciklike Arcanum divinae (AD) iz 1880. godine. U zakoniku kanonskoga prava iz 1917. godine (CIC 1917) pravo na odgoj i obrazovanje primarni je cilj i dužnost roditelja. Enciklika Divini illius Magistri (DIM) iz 1929. godine sljedeći je važan dokument promicanja ove teme. Doprinos Drugoga vatikanskoga sabora temi odgoja i obrazovanja analiziramo kroz Deklaraciju o kršćanskom odgoju Gravissimum educationis (GE). Ipak, poseban je naglasak stavljen na važeći Zakonik kanonskoga prava (CIC), odnosno odredbe usmjerene moralnomu, vjerskomu, kulturnomu, društvenomu i fizičkomu odgoju.

Drugi dio rada razmatra neke od dokumenata međunarodnoga prava. U prvom redu, predstavljena je Ženevska deklaracija o pravima djeteta iz 1924. godi-

* Doc. dr. sc. Klara Ćavar, Teološko-katehetski odjel Sveučilišta u Zadru. Adresa: Ul. Mihovila Pavlinovića 1, 23000 Zadar, Hrvatska. ORCID iD: http://orcid.org/0000-0002-2214-0229.

E-adresa:kcavar@unizd.hr

** Doc. dr. sc. Marija Džinić, Fakultet filozofije i religijskih znanosti Sveučilišta u Zagrebu. Adresa: Jordanovac 110, 10000 Zagreb, Hrvatska. ORCID iD: http://orcid.org/0000-0001-5385-5860.

E-adresa:m.dzinic@ffrz.unizg.hr 
ne, apelirajući na dostupnost sredstava nužnih razvoju materijalne, duhovne, ali i intelektualne dimenzije djece i mladih. Uz Opću deklaraciju o pravima čovjeka iz 1948. godine na poseban su način za temu bitne odredbe Konvencije o pravima djeteta iz 1989. godine. Pregled kanonskih i međunarodnih odredbi o pravu djeteta na odgoj i obrazovanje pomaže razlučiti narav toga prava te mogućnosti njegova provođenja u praksi.

\section{Pravo na odgoj i obrazovanje u kanonskom zakonodavstvu}

Crkvena tradicija ističe nužnu povezanost rađanja, odgoja i obrazovanja. Spomenute zadaće prvenstveno obvezuju roditelje (Zuanazzi, 2012, 47). Konkretna i plodna predanost obrazovanju pozitivan je pomak u napretku kulturnoga nasljeđa osiguravajući mladim naraštajima nasljedovanje mudrosti, znanja i vrijednosti.

U židovskoj tradiciji dati život potomstvu znači i brinuti za njegov rast i odgoj. Zadaća je oba roditelja, napose majke, svjedočiti i prenositi vjeru (Rocchetta, 2011, 228). U rimsko doba naglasak je stavljen na obiteljsku pedagogiju, a briga za odgoj i obrazovanje djece smatrana je neizostavnim aspektom povezanim s brakom i prokreacijom (Zuanazzi, 2012, 48). Kršćanska tradicija uzima u obzir i židovsku i rimsku tradiciju, vodeći računa o usklađenosti oba načela s evanđeoskim naukom (De Angelis, 2018, 21).

Stalne društvene promjene povezane s novim shvaćanjem i razumijevanjem djetinjstva, kao i obrazovnim modalitetima, utjecale su i na Crkvu pozvanu promisliti i osuvremeniti poglede na tu životnu etapu. Učiteljstvo Crkve sve je više isticalo obvezu roditelja brinuti o cjelovitom razvoju djece, napose o prenošenju vjere i odgoju u vjeri (De Angelis, 2018, 26).

Prije prikaza i analize izdvojenih dokumenata, potrebno je spomenuti kako se u crkvenim dokumentima uglavnom primjenjuje riječ "odgoj”, koja podrazumijeva pouku i obrazovanje kao djelatnosti kojima je cilj ostvariti odgoj ljudske osobe u njezinoj sveobuhvatnosti (Šalković, 2013, 124).

Enciklika o kršćanskom braku Arcanum divinae pape Lava XIII. od 10. veljače 1880. dokument je uzet kao polazišna točka razmatranja. Tema odgoja i obrazovanja prisutna je u različitim kontekstima, na poseban način u odnosu na ženidbu i njezinu društvenu važnost, odnosno na dužnost i obvezu bračnih drugova odgajati potomstvo. Ta enciklika upozorava na pogubne posljedice rastave ženidbenih drugova, štetnih dobrobiti, odgoju i obrazovanju djece.

\subsection{Odgoj i obrazovanje u zakoniku kanonskoga prava iz 1917. godine}

Zakonik kanonskoga prava iz 1917. temu obrazovanja posebno normira u kann. 1372-1383, utemeljenim na prethodnim normama, koje odgoj i obrazovanje smatraju odgovornošću i zadaćom roditelja. Tako kan. 1013 određuje da je prvotna svrha braka rađanje i odgajanje potomstva. Nadalje, analizom kan. 1113 možemo zamijetiti da su roditelji obvezni brinuti za vjerski, moralni, fi- 
zički, građanski odgoj djece te skrbiti za njihovo blagostanje. Fizički i moralni odgoj usmjerava formiranje volje i inteligencije djeteta, kako bi ono u budućnosti postalo uzornim članom Crkve i društva. Građanski odgoj imao je za cilj osigurati djeci adekvatnu formaciju kako bi postali korisni članovi društva. Spomenuti oblik odgoja podrazumijevao je, između ostaloga, odgovarajuće znanje o profanim disciplinama neophodnima za građanski život u skladu sa statusom i uvjetima života osobe (De Angelis, 2018, 50).

U predkoncilskoj Crkvi, odgoj potomstva promatran je kao jedna od svrha braka usko povezana s rađanjem, čime je više naglašena dužnost nego pravo roditelja odgajati djecu. Spomenuti način razmišljanja ostao je prisutan sve do proglašenja Zakonika kanonskoga prava iz 1983. godine (Falchi, 2010, 258).

\subsection{Tema odgoja $u$ enciklici Divini illius Magistri}

Divini illius Magistri enciklika je pape Pia XI. objavljena 31. prosinca 1929. godine posvećena temi kršćanskoga odgoja mladih. Pio XI. nudi važne smjernice prava na odgoj koje obvezuju roditelje, Crkvu i državu (Dau Novelli, 2017, 134). Ipak, prije ostalih, riječ je o isključivom, neotuđivom i nepovredivom pravu roditelja i obitelji (DIM, 58).

Pio XI. priznaje pravo i obvezu države u odgoju i obrazovanju vlastitih građana (Zuanazzi, 2012, 108). Država to pravo uživa jer je nadležna promicati vremenito opće dobro. U tom smislu, ima zadaću štititi i promicati pravo roditelja na kršćanski odgoj djece, a samim tim poštivati nadnaravno pravo Crkve u vezi s kršćanskim odgojem. Nepravedan je i nezakonit svaki odgojni i obrazovni monopol koji bi fizički ili moralno prisiljavao pohađanje državnih škola koje nisu u skladu sa kršćanskom savješću ili legitimnim izborom roditelja (DIM 38). Država je pozvana štititi pravo na odgoj i obrazovanje posebno kada roditelji fizički ili moralno nisu u stanju obnašati tu zadaću uslijed različitih nedostataka ili nesposobnosti (De Angelis, 2018, 59).

\subsection{Pravo na odgoj u deklaraciji Gravissimum educationis}

Novi dijaloški stil kojim Crkva, vjerna svojoj tradiciji, nudi kršćansku poruku suvremenomu svijetu, njegovoj kulturi i institucijama, prožima sva koncilska učenja. Iako je pitanje obrazovanja na neki način ostalo u "sjeni" dvaju ključnih konstitucija, Lumen gentium i Gaudium et spes, ipak čini fokus deklaracije Gravissimum educationis (Chambers, 2012, 188). Na Drugom vatikanskom saboru 28. listopada 1965. izglasana je deklaracija o kršćanskom odgoju Gravissimum educationis. Deklaracija je upečatljiv primjer odgovora na društvene i kulturne promjene onoga vremena (Madero, 2018, 56-59).

Deklaracija je manje rigidna od prethodnih dokumenata te otvorena dijalogu. Odgoj koji se može nazvati "pravim" usmjeren je izgradnji ljudske osobe i izgradnji dobrobiti društva. Referira se na niz prethodnih dokumenata učiteljstva, ali i na Opću deklaraciju o ljudskim pravima, a u svojem prvom broju ističe opće pravo na odgoj. U istom broju naglašava da djecu i mlade treba usmjeravati 
skladnomu razvoju fizičke, moralne i intelektualne sposobnosti da mogu aktivno sudjelovati u društvenom životu, biti otvoreni dijalogu i promicanju zajedničkoga dobra. U zadnjem dijelu prvoga broja obraća se vlastima i osobama zaduženim za odgoj pozivajući ih brinuti da mladi ne budu lišeni svetoga prava na odgoj, a članove Crkve potiče »da se velikodušno zalažu na čitavom području odgoja, naročito oko toga da se velike blagodati odgoja i obrazovanja što prije prošire na sve ljude cijeloga svijeta« (GE 1).

U drugom poglavlju stavlja naglasak na specifične elemente i ciljeve kršćanskoga odgoja. Korisno je i treće poglavlje posvećeno osobama i institucijama odgovornima za odgoj. Promatrajući protagoniste toga prava i zadaće, na prvo mjesto stavlja obitelj, odnosno roditelje. ${ }^{1}$

Obveza je države pomagati obiteljima u toj odgovornoj zadaći, promicati odgoj mladih, štititi prava i dužnosti roditelja i onih koji imaju udio u odgoju, pružati im pomoć te osnivati vlastite škole i odgojne institucije (GE 3).

\subsection{Odgoj i obrazovanje u Zakoniku kanonskoga prava iz 1983. godine}

Zakonik kanonskoga prava iz 1983. pitanjem odgoja i obrazovanja bavi se napose u trećoj knjizi naslova Naučiteljska služba Crkve (CIC kann. 747-833), iako su i u drugim dijelovima Zakonika sadržane odredbe u vezi s obrazovanjem. U Zakoniku se spominju različiti aspekti odgoja: kršćanski (CIC kann. 217 i 226 §1), katolički (CIC kann. 793-821), moralni i vjerski (CIC kann. 799 i 804 §1), kulturni, društveni i tjelesni odgoj (CIC kan. 1136). Aktualni Zakonik detaljnije se bavi odgojem, posvećuje mu više mjesta i promatra ga u širem kontekstu no prethodno zakonodavstvo (Degiorgi, 2015, 126). Kan. 217 govori o ciljevima kršćanskoga odgoja kao što je »zrelost ljudske osobe « i spoznaja »otajstava spasenja«. Pravo i obveza roditelja na odgoj djece regulirano je kan. 226 §2, a u kan. 1136 ponavlja dužnost i pravo roditelja brinuti o tjelesnom, društvenom i kulturnom životu djece. ${ }^{2}$

Odredbe sadrže nekoliko elemenata koje treba jasno istaknuti. Prvi se odnosi na odgovornost za odgoj, izričito navodeći da su roditelji, ili oni koji ih zamjenjuju, prvi odgajatelji vlastite djece (Eisenring, 1992, 86-88), što uzrokuje određene posljedice. Naime, ako je to prvotno i neotuđivo pravo i obveza roditelja, druge osobe, ali i institucije, građanska vlast i slično, u toj zadaći mogu sudjelovati samo kao pomoćnici roditelja i ne mogu ih zamijeniti. Roditelji katolici imaju pravo i dužnost izabrati za svoju djecu sredstva i ustanove koje nude i katolički odgoj. Pravo vjernika na kršćanski odgoj utemeljeno je na pravu svakoga čovjeka primiti odgovarajući odgoj i obrazovanje u skladu s vlastitim vjerskim uvjerenjima (Gan-

1 U svojoj analizi deklaracije Gravissiumum educationis Dolores R. Leckey $(2006,11)$ navodi kako je Christian Family Movement, nastao u SAD-u oko 1940. godine, bio usmjeren skrbi roditelja. Upravo su oni (ne Crkva ili država) prvi odgojitelji djece.

2 »Osoba koja je navršila osamnaest godina jest punoljetna; ispod te dobi osoba je maloljetna (CIC kan. 97 \$1). »Maloljetna osoba prije navršene sedme godine života naziva se dijete« (CIC kan. 97 §2). Usp. Degiorgi, 2015, 93-98. 
dia Barber, 2012, 33) ${ }^{3}$. Roditelji imaju pravo primiti, i od građanskoga društva, pomoć potrebnu za katolički odgoj djece. Ta pomoć nije privilegij, nego pravo, i tko niječe to pravo, zlorabi ovlasti.

Zakonik kanonskoga prava u kan. 800 potvrđuje pravo Crkve osnivati i voditi škole bilo kojega smjera, vrste i stupnja. Pravu Crkve idu u prilog i povijesne činjenice jer je odgojna djelatnost, tijekom stoljeća, bila njezina isključiva funkcija (Chiappetta, 1996, 42). Već od petoga stoljeća počele su djelovati župne, biskupske, katedralne i redovničke škole. Tijekom stoljeća pojavile su se redovničke zajednice kojima je prvotna briga bila upravo odgoj djece i mladeži (Ćavar i Vujica, 2019, 227).

Škole imaju iznimnu ulogu u odgoju i roditeljima su glavna pomoć u obavljanju odgojiteljske dužnosti (CIC kan. 796 §1). Škola je roditeljima glavna i neprocjenljiva pomoć u obnašanju njihove odgojiteljske dužnosti, a roditelji su pozvani tijesno surađivati s nastavnicima kojima su povjerili djecu (Eisinger, 2012, 106-107).

Kan. 795 definira svrhu i sadržaj odgoja te određuje da pravi odgoj mora ići za cjelovitim oblikovanjem ljudske osobe. Posebno se ističe da se djeca i mladi trebaju odgajati kao odgovorni i djelatni sudionici u životu zajednice, za aktivno sudjelovanje u društvu, kako bi, kada postanu punoljetni, dali vlastiti doprinos društvu kojemu pripadaju (Degiorgi, 2015, 129). Odgoj, nadalje, ima za cilj skladno razvijati različite vještine kako bi stekli »savršeniji osjećaj odgovornosti i ispravnu uporabu slobode « (CIC kan. 795).

Kanonsko zakonodavstvo jasno određuje primarnu i nezamjenjivu ulogu roditelja i obitelji u obrazovanju mladih te sekundarnu ulogu ostalih subjekata. ${ }^{4}$

\subsection{Tema odgoja u apostolskoj pobudnici Amoris laetitia}

Postsinodalna apostolska pobudnica pape Franje o ljubavi u obitelji Amoris laetitia nastala je nakon treće izvanredne i četrnaeste redovne biskupske sino$\mathrm{de}^{5}$ posvećene suvremenoj obiteljskoj problematici. Pobudnica promiče život kršćanskih obitelji nudeći smjernice pastoralu u službi obitelji. Temom odgoja pobudnica se bavi na osobit način u br. 80-85 i u sedmom poglavlju naslovljenom Pojačati odgoj djece. ${ }^{6}$ Ističe da je »jedan od temeljnih izazova s kojim se suočavaju današnje obitelji bez sumnje odgoj, koji današnja kulturna stvarnost i veliki utjecaj medija čine još zahtjevnijim i kompleksnijim «(AL 84). Naglašeno je kako je cjeloviti odgoj djece »veoma važna dužnost« i u isto vrijeme »osobito pravo roditelja«. Nije riječ samo o obvezi, nego i o neotuđivu pravu koje su roditelji

3 Govorimo o pravu koje država treba priznati u skladu s načelom vjerske slobode (usp. Dignitatis humanae, 5).

4 Pravo odgoja u skladu s vlastitim ćudorednim i vjerskim uvjerenjima te slobodu pri izboru škole potvrđuje članak 5. Povelje o pravima obitelji od 22. listopada 1983. (Sveta Stolica, 2009, 14-15).

5 Treća izvanredna biskupska sinoda održana je u listopadu 2014. godine, a četrnaesta redovna biskupska sinoda u listopadu 2015. godine.

6 Pobudnica Familiaris consortio jednako tako dotiče pitanje odgoja, naglašavajući kako je odgojno pravo i dužnost roditelja nešto bitno, izvorno, nezamjenljivo i neotuđivo (FC 36-41). 
dužni braniti. Dužnost je države pratiti i podupirati roditelje u njihovoj odgojnoj zadaći. Upravo odnos između roditelja i općenito život u obitelji trebaju postati modelom odgoja (Fares, 2016, 358). Iako škola ima bitnu ulogu u odgoju, ona ne može zamijeniti ulogu roditelja i može ju samo nadopuniti (Séìde, 2016, 172-173).

\section{Pravo na obrazovanje u međunarodnom pravu}

Više međunarodnih dokumenata apelira za ostvarenje prava na obrazovanje, a ovdje se ograničavamo samo na neke od njih. Opetovano osvješćivanje toga prava i obveze osiguravanja optimalnih uvjeta kojima će se ono konkretno ostvariti opravdano je i jasno. Naime, upravo je odgojno-obrazovna dimenzija rasta i razvoja djece i mladih ključna za njihovo kasnije uključivanje u svijet odraslih. Upravo zato »nije svejedno kakav će odgoj i obrazovanje današnji mladi dobiti, jer upravo o njima ovisi smjer u kojemu će se svijet razvijati« (Maleš, 2000, 59).

Povijest ukazuje na razvidno različit položaj i ulogu djece u obiteljskom i javnom životu (Rosić i Zloković, 2002, 11-21). Pitanje pravnoga statusa djece ovisilo je o kulturološko-civilizacijskom položaju zajednice. »Čak su i u istom povijesnom razdoblju u istom društvu, shvaćanja prirode djeteta bila različita, ovisno o društvenom sloju ili kulturi kojima dijete pripada« (Koren, 2005, 269). Tako je, primjerice, u periodu koji je prethodio 20. stoljeću prevladavala tendencija usmjeravanja obrazovnoga sustava na odraslu populaciju. Bitnu ulogu u promicanju te vrste prava imao je poljski liječnik i pedagog Janusz Korczak, znakovito nazvan "ocem prava djece". Njegov pedagoški pristup, prije svega, temeljio se je upravo na poštivanju prava djeteta usmjeravajući odgoj djeteta njegovoj individualnosti (Bašić, 2011, 24).

\subsection{Dijete kao subjekt vlastitoga razvoja}

Gotovo potpuno zanemarivanje prava djeteta doživjelo je veliki obrat tek u 20. stoljeću. Uvažavanje djeteta kao subjekta vlastitoga razvoja »osnažilo je perspektivu usmjerenu na dijete « (Bašić, 2011, 25). Paralelno započinje sustavni rast svijesti o potrebi poštivanja djece i njihovih prava, a time i ekspanzija obrazovanja, čiji se uzroci nalaze $\mathrm{u}$ »društveno-ekonomskim promjenama, suvremenom shvaćanju znanosti i njezine nužnosti za suvremeni život « (Zaninović, 1988, 310). Unatoč brojnim prednostima, dokumenti o pravima djece sadrže i neke proturječnosti. »Iako ističu dječje pravo na fizički i mentalni identitet i integritet, pravo na autonomni izbor i odlučivanje, pravo na slobodno izražavanje mišljenja, pravo na udruživanje i djelovanje, istovremeno u njima prevladava zaštitnički odnos prema djeci koja se na taj način tretiraju kao ranjiva i nezrela, čime ih se stavlja u marginalan položaj« (Kopić i Korajac, 2010, 46).

Bitno je naglasiti kako je »diskurs prava djece pretežito pravni diskurs, a kao takav prihvaćen je u mnogim znanstvenim disciplinama« (Polić, 2017, 187). Počiva na shvaćanju djeteta kao djelatnoga i aktivnoga bića koje participira u društvu. Najjasniji je primjer diskursa prava djeteta Konvencija o pravima djeteta iz 1989. godine (Polić, 2017, 187), u kojoj se po prvi puta djetetu pristupa kao subjektu 
S pravima. S razlogom je stoga smatrana »revolucionarnim dokumentom « (Širanović, 2011, 311).

Spomenutoj Konvenciji prethodili su jednako važni dokumenti (Moody, 2016, 95). Prvi među njima nastao je neposredno nakon Prvoga svjetskoga rata, 1924. godine, kada je Liga naroda usvojila poznatu Ženevsku deklaracija o pravima djeteta, koja u pet temeljnih točaka izdvaja prava djeteta. Taj prvi službeni dokument o pravima djeteta zasluga je poznate borkinje za prava djece Eglantyne Jebb (Macinai, 2006, 61-62)7. Iako iznimne važnosti, Ženevska deklaracija prihvaćena je prvenstveno kao moralni apel, pravno neobvezujući. S druge strane, ta je deklaracija »prvi pokušaj postavljanja međunarodnih standarda na području ljudskih prava« (Koren, 2005, 270).

Ženevska deklaracija jasno naglašava obvezu odraslih skrbiti o odgoju i zaštiti prava djeteta promičući pravo »na tjelesni i duhovni razvoj; pravo djeteta na ishranu, zdravstvenu njegu i zaštitu; pravo na pomoć u nevolji, zaštitu od iskorištavanja te podizanje djeteta na način da ono postane svjesno svojih sposobnosti koje služe ljudskom društvu « (Kopić i Korajac, 2010, 46). Iz teksta je razvidno kako djecu ne smatra autonomnim subjektima prava ni sposobnima donositi odluke neovisno od odraslih. Prema tomu, zadatak je odraslih osigurati im sva pripadajuća prava do trenutka stjecanja osobne, društvene i pravne neovisnosti. Pragmatične smjernice Ženevske deklaracije utjecale su na daljnji razvoj diskursa prava djeteta. U svjetlu navedenih pet točaka države potpisnice dužne su usmjeravati, između ostaloga, obrazovnu i društvenu politiku.

Iako izričito ne spominje pravo na obrazovanje, obveza »izvesti na put da može zarađivati za život « usmjerena je upravo određenoj vrsti obrazovanja djeteta te otkrivanja i razvoja talenata i vještina koje posjeduje.

\subsection{Pravo djeteta na obrazovanje}

Pravo na obrazovanje stupnjevito se je razvijalo. »Od stare Grčke do današnjih dana isticana je važnost obrazovanja za razvoj pojedinca i čitave društvene zajednice, no tek je humanizam prepoznao u obrazovanju temelj za izgradnju slobodnog društva « (Maleš, 2002, 389).

Obrazovanje možemo definirati kao »organizirani pedagoški proces stjecanja znanja i razvijanja spoznaja « (Ravlić, 2006, s. v. obrazovanje). Iako ga se često poistovjećuje s terminom izobrazba, međusobno se razlikuju jer je izobrazba »poseban oblik školovanja koje je usmjereno na uža, ciljana znanja i umijeća [...] Izobrazba se zbog toga odnosi na stručna i primjenjiva znanja, često povezana sa strukom i profesijom « (Kovačec, 2003, s. v. izobrazba). Razvidno je kako je obrazovanje puno širi pojam, koji u sebi sadrži i izobrazbu. U užem smislu pak obrazovanje obuhvaća »stjecanje znanja i razvijanje sposobnosti; iz toga proizlaze i materijalni/kognitivni zadatci obrazovanja (znanje) i funkcionalni, formalni, formativni, psihomotorički ili operativni (sposobnosti) zadatci« (Ravlić, 2006, s. v. obrazovanje). 
Pravo na obrazovanje, prema tomu, podrazumijeva četiri dimenzije: raspoloživost, dostupnosti, prihvatljivost i prilagodljivost (Tomaševski, 2001, 12). ${ }^{8}$ Raspoloživost polazi od prava na obrazovanje kao građanskoga i političkoga prava. Ono podrazumijeva obvezu države dopustiti osnivanje obrazovnih institucija od strane nedržavnih subjekata. S druge strane, pravo na obrazovanje kao ekonomsko i socijalno pravo pretpostavlja obvezu države osnivati i financirati naznačenu vrstu ustanova s ciljem obrazovanja za sve. Dostupnost obrazovanja podrazumijeva obvezu države osigurati besplatno osnovno obrazovanje za sve, a srednje i visoko prema određenim uvjetima. Prihvatljivost obrazovanja uključuje obvezu osiguravanja kvalitete obrazovanja, odnosno odgoj i obrazovanje prema određenim standardima. Na posljetku, prilagodljivost se obrazovanja odnosi na obvezu države prilagoditi odgoj i obrazovanje različitim grupama djece i mladih (Tomaševski, 2001, 13-15).

Izvori međunarodnih dokumenata o pravu na obrazovanje sadrže tri zajednička elementa: besplatno i obvezatno osnovno obrazovanje, garanciju obrazovna pluralizma i slobodu roditelja izabrati vrstu obrazovanja za svoju djecu (Marchisio, 2018, 269) $)^{9}$.

\subsubsection{Pravo na obrazovanje u Općoj deklaraciji o ljudskim pravima}

Opća deklaracija o ljudskim pravima prvi je dokument usmjeren zaštiti ljudskih prava proglašen na međunarodnoj razini. Dana 10. prosinca 1948. godine usvojena je i proglašena na Općoj skupštini Ujedinjenih naroda. Već u preambuli Opće deklaracije izričito je istaknuto kako je cilj njezina objavljivanja »kako bi svaki pojedinac i svako tijelo u društvu, imajući ovu Deklaraciju stalno na umu, težili poučavanjem i obrazovanjem promicati poštovanje ovih ljudskih prava i sloboda te kako bi se postupnim domaćim i međunarodnim mjerama osiguralo njihovo opće i djelotvorno priznanje i primjena među narodima država članica i među narodima na područjima pod njihovom jurisdikcijom «(Opća deklaracija o ljudskim pravima, 2009, Preambula).

Sastavni su dio ljudskih prava i prava djece, a posebno mjesto koje ona zauzimaju u društvu prepoznaje Opća deklaracija (Koren, 2005, 268).

Deklaraciju čini 30 članaka, između kojih je i pravo na obrazovanje, kako čitamo u članku 26. Pravo na obrazovanje pripada svakomu pojedincu, neovisno o nacionalnoj, religijskoj, društvenoj ili kojoj drugoj vrsti pripadnosti. Štoviše, to pravo negira bilo kakvu vrstu diskriminacije. Upravo je zato naglasak na njegovoj općoj dostupnosti. Razvidno je, nadalje, kako obrazovanje nije samo sebi cilj. Ono je sredstvo razumijevanja, tolerancije i solidarnosti među narodima, rasnim ili vjerskim grupama. Drugim riječima, obrazovanje u tom kontekstu možemo promatrati kao sredstvo ostvarenja drugih prava usmjerenih razvoju i jačanju kvalitete života. Njime pojedinci razvijaju svijest ne samo vlastitih prava, nego i 
pripadajućih obveza i odgovornosti prema drugima. Garantirati pristup pravu na obrazovanje čini temeljnu pretpostavku osiguranja potpuna ostvarenja temeljnih ljudskih prava (Marchisio, 2018, 268).

Jednako kao i u analiziranim crkvenim dokumentima, roditeljima je dano pravo prvenstva izbora vrste obrazovanja za svoju djecu. Opisane uvijete obrazovanja dužne su osigurati pojedine države (Randazzo, 2008). Iako govorimo o moralnoj i etičkoj obvezi država potpisnica, taj je dokument potaknuo niz zakonodavnih odluka na lokalnim razinama, a kojima je pravo na obrazovanje jasno artikulirano (McCowan, 2010, 510-511).

Slijedeći ideju zaštite ljudskih prava, Opća skupština Ujedinjenih naroda usvojila je 1959. godine Deklaraciju o pravima djeteta. Unutar toga dokumenta po prvi puta su istaknuta temeljna prava djeteta, između kojih i pravo na obrazovanje, koje je detaljnije definirala Konvencija o pravima djeteta (Maleš, 2002, 390).

\subsubsection{Konvencija o pravima djeteta}

Konvencija o pravima djeteta usvojena je na Glavnoj skupštini Ujedinjenih naroda 20. studenoga 1989. godine, a sadržajno obuhvaća prava i slobode koje se stječu samim rođenjem. Konvencija »sadrži opsežan skup međunarodnih pravnih normi posvećenih zaštiti i dobrobiti djece. Tim se međunarodnim dokumentom uvode neki novi (obiteljsko) pravni standardi (npr. najbolji interes djece) i pojmovi (npr. zajednička odgovornost roditelja); dječje se potrebe kategoriziraju i dobivaju svoje pravno obilježje, a država se obvezuje na poduzimanje potrebitih mjera za provedbu Konvencije «(Hrabar, 1994, 264).

Posebnost Konvencije, u odnosu na prethodno spomenute dokumente, u činjenici je kako je riječ o pravnom aktu sa zakonskom snagom. Obvezuje stranke pridržavati se sadržanih odredbi, uključujući pravo nadzora nad njihovom provedbom i primjenom među državama potpisnicama (Maleš, 2000, 58). Zato ju je potrebno promatrati kao cjelinu (Maleš, 2002, 391).

Iz sadržaja članka 28 razvidna je obveza dostupnosti obrazovanja. Potvrđuje obvezu osnovnoga obrazovanja ističući nužnost »poticati razvoj različitih oblika srednjoškolskog obrazovanja, uključujući opću i stručnu izobrazbu, te ih učiniti raspoloživim i dostupnim svakom djetetu te poduzeti primjerene mjere kao što su uvođenje besplatne izobrazbe i osiguranje materijalne podrške kad je ona potrebna «, te »svim prikladnim sredstvima učiniti više i visoko obrazovanje dostupno svima na temelju sposobnosti« (Konvencija o pravima djeteta).

Uz standardno isticanje prava na obrazovanje, Konvencija ide puno dalje. Veliki naglasak stavlja na kvalitetu obrazovanja. Tako u članku 29 čitamo kako odgoj i obrazovanje treba usmjeriti »punom razvoju djetetove osobnosti, nadarenosti, duševnim i tjelesnim sposobnostima«, ali i »poticanju poštivanja djetetovih roditelja, njegova kulturnog identiteta, jezika i vrjednota, nacionalnih vrjednota zemlje u kojoj dijete živi i zemlje iz koje potječe te poštivanje civilizacije koje se od njega razlikuje « (Konvencija o pravima djeteta).

Temeljni smisao Konvencije usmjerenost je cjelovitu razvoju djeteta, koji uključuje raspoloživo, dostupno, prihvatljivo i prilagodljivo obrazovanje. 


\section{Zaključak}

Pravo na obrazovanje temeljna je pretpostavka razvoja i stabilnosti pojedinca te najbolje sredstvo društvenoga razvoja. Upravo zato nužno je osigurati to isto pravo svima, isključujući svaku vrstu diskriminacije i isključivosti. Crkva je, ne samo praksom, nego i konkretnim dokumentima oduvijek poticala odgoj i obrazovanje $\mathrm{Na}$ temelju dokumenata analiziranih u ovom radu možemo zaključiti kako je njihov zajednički element aktivna skrb Crkve u promicanju obrazovanja. U predkoncilskoj Crkvi, odgoj potomstva promatran je kao jedna od svrha braka usko povezana s rađanjem. Utoliko je dužnost prednjačila pred pravom roditelja. Spomenuti sustav promišljanja ostao je prisutnim sve do proglašenja novoga Zakonika kanonskoga prava iz 1983. godine. Aktualnim kanonskim zakonodavstvom jasno je određena primarna i nezamjenljiva uloga roditelja i obitelji u obrazovanju mladih. Crkva, škola, građansko društvo i država imaju važnu ulogu u odgojnoj zadaći, ali sporednu u odnosu na roditelje. Obiteljsko obrazovanje treba uzeti za polazišnu točku ostalih obrazovnih djelovanja, priznajući roditeljima pravo koristiti one obrazovne institucije koje više odgovaraju njihovu vlastitomu moralnomu, vjerskomu i etičkomu uvjerenju. Međunarodno pravo, jednako kao i kanonsko, apelira za ostvarenje prava na obrazovanje, jednoga od temeljnih ljudskih prava. Među inima izdvajamo Konvenciju o pravima djeteta. Posebnost je toga dokumenta, u odnosu na prethodno spomenute, u činjenici da je riječ o pravnom aktu sa zakonskom snagom. Obvezuje stranke pridržavati se sadržanih odredbi, uključujući pravo nadzora nad njihovom provedbom i primjenom među državama potpisnicama. Kako je Konvencija nastala 1989. godine, razložno bi bilo smatrati da je zaživjela u praksi. Ipak, svjedoci smo kako je stvarno stanje drugačije. Napose se je ta činjenica aktualizirala u vremenu pandemije. Problem isključenja milijuna djece iz sustava obrazovanja poprimio je puno šire razmjere. Potrebno je stoga usmjeriti se očuvanju toga prava i učiniti obrazovanje raspoloživim, prihvatljivim, prilagodljivim i dostupnim. Upravo te četiri dimenzije, postulati prava na obrazovanje, osiguranje su budućnosti ljudskoga društva.

\section{Literatura}

AD. Arcanum divinae. (10. veljače 1880.) Lav XIII., Arcanum divinae epistola encyclica. U: Documenta Latina. URL: https://www.vatican.va/content/leo-xiii/la/encyclicals/ documents/hf_l-xiii_enc_10021880_arcanum.html (23.11.2021.)

AL. Amoris laetitia. (19. ožujka 2016.) Franjo, Amoris laetitia: Radost ljubavi. Zagreb: Kršćanska sadašnjost, 2016.

Bašić, Slavica (2011). (Nova) slika djeteta u pedagogiji djetinjstva. U: Dubravka Maleš (ur.), Nove paradigme ranog odgoja (str. 19-37). Zagreb: Filozofski fakultet.

Chambers Michael (2012). Students who are not Catholics in Catholic schools: Lessons from the Second Vatican Council about the Catholicity of schools. International Studies in Catholic Education, 4(2), 186-199.

Chiappetta, Luigi (1996). Il Codice di diritto canonico: Commento giuridico-pastorale. Roma: EDB. 
CIC 1917. Codex Iuris Canonici 1917. U: Codex Iuris Canonici fontium annotatione auctus MDCCCCXVII: Kodeks kanonskog prava s izvorima 1917.: Uređen po odredbi sv. oca pape Pija X., proglašen po nalogu pape Benedikta XV. Zagreb: Glas Koncila, 2007.

CIC. Codex Iuris Canonici. Ivan Pavao II., Zakonik kanonskoga prava. Zagreb: Glas Koncila, 1996.

Ćavar, Klara; Vujica, Vikica (2019). Interkulturalni odgoj i obrazovanje u katoličkim školama. U: Smiljana Zrilić (ur.), Identitet i različitost u odgoju i obrazovanju (str. 223-237). Zadar: Sveučilište u Zadru.

Dau Novelli, Cecilia (2017). Matrimonio e famiglia nel magistero dei pontefici del ' 900. Rivista di Storia della Chiesa in Italia, 1, 131-145.

De Angelis, Francesco (2018). L'educazione del minore e la libertà religiosa: Profili di riflessione nel diritto canonico e nel diritto internazionale. Città del Vaticano: Lateran University Press.

Degiorgi, Giorgio (2015). I minori nella legislazione della Chiesa. Venezia: Marcianum Press.

DH. Dignitatis humanae. Drugi vatikanski koncil, deklaracija Dignitatis humane o vjerskoj slobodi. U: Josip Turčinović (ur.), II vatikanski koncil: Dokumenti: Latinski i hrvatski (str. 469-489). Zagreb: Kršćanska sadašnjost, 19701.

DIM. Divini illius Magistri. (31. prosinca 1929.) Pio XI., Litterae encyclicae Divini illius Magistri. U: Documenta Latina. URL: https://www.vatican.va/content/pius-xi/la/encyclicals/documents/hf_p-xi_enc_31121929_divini-illius-magistri.html (23.11.2021.)

Eisenring, Gabriela (1992). Il diritto del minorenne all'educazione cristiana nella Chiesa. Fidelium Iura, 2, 85-110.

Falchi, Francesco (2010). Educazione religiosa della prole e separazione dei coniugi: Dallo jus decretalium al Codice del 1983. U: Kowal Janusz i Joaquín Llobell (ur.), Iustitia et iudicum (str. 1171-1192). Città del Vaticano: Libreria Editrice Vaticana.

Fares, Diego (2016). Educare i figli secondo "Amoris laetitia": La pedagogia di papa Francesco. La civiltà cattolica, 167, 356-358.

FC. Familiaris consortio. (22. studenoga 1981.) Ivan Pavao II., Familiaris consortio: Obiteljska zajednica: Apostolska pobudnica o zadaćama kršćanske obitelji u suvremenom svijetu. Zagreb: Kršćanska sadašnjost, 1997.

Gandia Barber, Juan Damian (2012). El derecho de los fieles a la palabra de Dios y el deber del anuncio del Evangelio. Anuario de Derecho Canonico, 1 (supl. 1), 15-69.

GE. Gravissimum educationis. (28. listopada 1965.) Drugi vatikanski koncil, Deklaracija Gravissimum educationis o kršćanskom odgoju. U: Josip Turčinović (ur.), II vatikanski koncil: Dokumenti: Latinski i hrvatski (str. 360-380). Zagreb: Kršćanska sadašnjost, 1970.

Hrabar, Dubravka (1994). Prava djece u obitelji. Revija za socijalnu politiku, 1(3), 263-267.

Hrabar, Dubravka (2018). Odjek roditeljskih vjerskih i filozofskih uvjerenja na odgoj i obrazovanje djece u hrvatskoj legislativi. Zbornik Pravnog fakulteta u Zagrebu, 68(3-4), 319-336.

Kerber-Ganse, Waltraut, Eglantyne Jebb-A Pioneer of the Convention on the Rights of the Child, The International Journal of Children's Rights, 23 (2015) 2, 272-282.

Klles, Steven; Thapliyal, Nisha (2007). The right to education: The work of Katarina Tomasevski. Comparative Education Review, 51(4), 497-510.

Konvencija o pravima djeteta (s. a.). Glavna skupština Ujedinjenih naroda, Konvencija o pravima djeteta. (20. studenoga 1989.) URL: https://www.unicef.hr/wp-content/ uploads/2017/05/Konvencija_20o_20pravima_20djeteta_full.pdf (24.11.2021.) 
Kopić, Željka; Korajac, Valerija (2010). Djeca i djetinjstvo u dokumentima o pravima djeteta. Život $i$ škola, 24(2), 45-54.

Koren, Marian (2005). Ljudska prava djece: Pravo na informaciju. Dijete i društvo, 6(2), 267-287.

Kovačec, August (ur.) (2003). Hrvatska enciklopedija: 5: Hu-Km. Zagreb: Leksikografski zavod Miroslav Krleža.

Leckey, Dolores R. (2006). The Laity and Christian Education: Apostolicam Actuositatem, Gravissimum Educationis. New York: Paulist Press.

Macinai, Emiliano (2006). L'infanzia e i suoi diritti: Sentieri storici, scenari globali e emergenze educative. Pisa: ETS.

Madero, Cristóbal (2018). 50 years of the Declaration on Christian Education Gravissimum educationis: A review of its reception in Latin America. International Journal of Christianity \& Education, 22(1), 55-63.

Maleš, Dubravka (2000). Značenje odgoja i obrazovanja za prava djeteta. Dijete i društvo, 2(1), 57-64.

Maleš, Dubravka (2002). Obrazovanje-osnovno ljudsko pravo. Napredak, 143(4), 389402.

Marchisio, Sergio (2018). Diritto all'istruzione e integrazione dei rifugiati. Ordine internazionale e diritti umani, 267-275.

McCowan, Tristan (2010). Reframing the universal right to education. Comparative Education, 46(4), 509-525.

Moody, Zoe (2016). Les droits de l'enfant Genèse, institutionnalisation et diffusion (1924 1989). Suisse: Éditions Alphil-Presses universitaires suisses.

Opća deklaracija o ljudskim pravima (2009). Opća skupština Ujedinjenih naroda, Opća deklaracija o ljudskim pravima. Narodne novine, 12, dokument br. 143. URL: https:// narodne-novine.nn.hr/clanci/medunarodni/2009_11_12_143.html (24.11.2021.)

Polić, Petra (2017). Prava djece-izazovi u kritičkom pristupu. U: Dubravka Maleš et al. (ur.), Pravo djeteta na odgoj i obrazovanje: Teorije, politike i prakse (str. 187-198). Zagreb: Filozofski fakultet.

Randazzo, Barbara (ur.) (2008). Lo straniero nella giurisprudenza della Corte Europea dei Diritti dell'Uomo. Madrid: s. 1. URL: https://www.asgi.it/wp-content/uploads/2014/07/ lo.straniero.nella_.giurisprudenza.della_.corte_.europea.dei_diritti.dell_.uomo_.pdf (24.11.2021.)

Ravlić, Slaven (ur.) (2006). Hrvatska enciklopedija: 8: O-Pre. Zagreb: Leksikografski zavod Miroslav Krleža.

Rocchetta, Carlo (2011). Teologia della famiglia: Fondamenti e prospettive. Bologna: EDB.

Rosić, Vladimir; Zloković, Jasminka (2002). Prilozi obiteljskoj pedagogiji. Rijeka: Filozofski fakultet.

Séide, Martha (2016). La prospettiva educativa dell'Esortazione apostolica post-sinodale: Amoris Laetitia. Rivista di scienze dell'educazione, 54(2),169-183.

Sveta Stolica (2009). Povelja o pravima obitelji od Svete Stolice predložena svim osobama, ustanovama i predstavnicima vlasti nadležnima za poslanje obitelji u suvremenom svijetu. Zagreb: Kršćanska sadašnjost.

Šalković, Josip (2013). Pravni elementi evangelizacijskog poslanja Crkve. Zagreb: Glas Koncila.

Širanović, Ana (2011). Prava djeteta između zaštite odraslih i djetetovog vlastitog mišljenja i djelovanja 
Tomaševski, Katarina (2001). Human Rights Obligations: Making Education Available, Accessible, Acceptable and Adaptable. Sweden: Novum Grafiska.

Zaninović, Mate (1988). Opća povijest pedagogije. Zagreb: Školska knjiga.

Zuanazzi, Ilaria (2012). L'ordinatio ad educationem prolis del matrimonio canonico. Napoli: Jovene.

\section{The Child's Right to Education in Canonical and International Legislation}

Klara Ćavar*, Marija Džinić***

\section{Summary}

The right to an education is a fundamental human right. Church legislation protects $i t$, promotes it, and regulates it by means of its own provisions. In the first part of this presentation, we analyze the historical development of the right to education in ecclesiastical legislation. It begins with the encyclical Arcanum divinae sapientie and ends with the provisions of the Code of Canon Law of 1917. In the Code, the right to education is presented as the primary goal and obligation of parents. The declaration on Christian Education Gravissimum educationis confirms the traditional postulate of education. However, special emphasis is placed on the provisions of the current Code of Canon Law.

Some documents based on international law are also considered in the presentation. First, the Geneva Declaration is put forward, according to which children should have access to the means necessary for their development, whether material or spiritual. The provisions of the Universal Declaration of Human Rights, which states in Article 26 that this is a right to which everyone is entitled. Particularly relevant to our topic are the provisions of the Convention on the Rights of the Child, proposed in Articles 28-2 which deal with education in a special way. An overview of the canonical and international provisions on the right of the child to education helps to distinguish the nature of this right and the possibilities for its practical implementation.

Keywords: child; upbringing; education; canonical legislation; international legislation

* Klara Ćavar, Ph.D., Assistant Professor, Department of Religious Sciences, University of Zadar. Address: Ul. Mihovila Pavlinovića 1, 23000 Zadar, Croatia. E-mail: kcavar@unizd.hr

** Marija Džinić, Ph.D., Assistant Professor, Faculty of Philosophy and Religious Studies, University of Zagreb. Address: Jordanovac 110, 10000 Zagreb, Croatia. E-mail:m.dzinic@ffrz.unizg.hr 